\title{
Assessing the Environmental Benefits of Watershed Develop- ment: Evidence from the Indian Semi-Arid Tropics
}

\author{
Suhas P Wani', KH Anantha, TK Sreedevi, R Sudi, SN Singh, Marcella D’Souza² \\ ${ }^{1}$ International Crops Research Institute for the Semi-Arid Tropics (ICRISAT) Patancheru 502 324, Andhra \\ Pradesh, India. ${ }^{2}$ Watershed Organisation Trust (WOTR), Ahmednagar 414 001, Maharashtra, India.
}

Received: April 30, 2010 / Accepted: December 16, 2010

\section{$M$}

Abstract any environmental benefits result from watershed interventions in the semi-arid tropics. Environmental benefits may be defined as the condition and process through which ecosystems sustain and fulfill human life, including the provision of food and other goods. The spillover effects of these benefits range from an increase in household welfare condition to ecosystem sustainability. An attempt is made in this paper to assess these benefits in the context of Indian Semiarid tropics using primary data collected from two micro watersheds (Rajasamadhiyala and Shekta watersheds). Results indicate that groundwater availability has substantially increased and soil conservation has brought changes in cropping patterns with high-value crops. Rainwater harvesting through check dams, causeway cum check dams, percolation tanks, farm ponds and earthen bunds have significantly increased water storage capacity and water availability along with doubling the production of major crops. Significant increases in irrigated area, cropping intensity along with diversification of crops from traditional to commercial cash crops were recorded in the watersheds. Assessing the environmental benefits accrued from the watershed development approach may lead to the identification of 'keystone elements' in a landscape that have a substantial impact by providing multi-functions. The integrated watershed management practices adopted in the two micro watersheds substantially improved the sustainability in these watersheds. Using available methods we have assessed the environmental benefits of micro watersheds in the Indian semi-arid tropics.

Key words: watershed, environmental benefits, groundwater, diversification

* Corresponding author: s.wani@cgiar.org

\section{Introduction}

Looming water scarcity over large parts of the world and increased withdrawal by agriculture from $2500 \mathrm{~km} 3$ in 2000 to $3200 \mathrm{~km} 3$ by 2025 (Shiklomanov, 1999) has attracted the attention of policy makers and researchers for achieving food and water security. It is estimated that by 2025 , one third of the world's population (especially in the developing countries) would face severe water scarcity (Secklar et al., 1998). To achieve food security, minimize water conflicts and reduce poverty it is essential to increase productivity of rainfed systems by harnessing the existing potential (Wani et al., 2003a). In 1990s the government of India adopted watershed management on a large scale as a strategy to address these problems through conserving rainwater and soil for increasing production of rainfed systems (Wani and Ramakrishna, 2005; Wani et al., 2008a).

Watershed intervention is an important policy strategy to enhance rural livelihoods by undertaking resource conservation and management activities. Natural resource conservation and human resource management are goals of watershed development strategies carried out by government and non-governmental agencies with collective community involvement. One key element of watershed development interventions in arid and semi-arid tropics is the concept of livelihood security and environmental sustainability. Social, economic, and environmental services accrued from watershed interventions have strengthened rural livelihood systems (Sreedevi et al., 2006). In particular, these services are defined as the condition and process through which ecosystems sustain and fulfill human life, including the provision of food and other goods (Rosegrant, 2002). The conservation and management of natural resources provide huge economic benefits and thereby ensuring sustainable livelihoods of marginalized sections of the community (Shiferaw et 
al., 2006).

The watershed strategy is significant in conserving and managing scarce resources such as land and water to meet growing demand for food. The watershed management approach was adopted to conserve rainwater, minimize land degradation, improve groundwater recharge, increase crop intensity and productivity (Kerr et al., 2000). Watershed development programs not only enhanced the crop productivity but also minimize the risk of degradation of natural resource base. The experiences in semi-arid areas have already shown that watershed development programs have become engines of development especially to reduce poverty, maintain food, fodder and fuel security in a sustainable manner for a large population (Wani et al., 2003b; 2008b).

The purpose of this paper is to assess the potential environmental and ecological benefits in watershed areas taking the environmental services approach. The paper specifically focuses on the benefits such as soil conservation and water harvesting, groundwater recharge, land use and productivity, and crop diversification as the means to achieve efficiency of key natural resources such as land and water.

\section{Materials and Methods}

\section{Rajasamadhiyala Watershed}

Rajasamadhiyala micro-watershed (Micro-watershed is defined as "a small first and second class watershed, in which a certain number of families live (community) making use and managing the resources of the area, mainly the soil, water, vegetation, including crops and native vegetation and fauna, including domestic and wild animals. From the operational point of view, the micro-watershed has an area that may be planned by a technician counting on local resources and/or a number of families that may be treated as a social nucleus that shares some common interests' (http://www.rlc.fao.org/en/tierra/micro.htm)) at latitude $22^{\circ} 8^{\prime} 15^{\prime \prime} \mathrm{N}$ to $22^{\circ} 13^{\prime} 15^{\prime \prime} \mathrm{N}$, and longitude $70^{\circ}$ $54^{\prime} 30^{\prime \prime} \mathrm{E}$ to $70^{\circ} 59^{\prime} 15^{\prime \prime} \mathrm{E}$ covering over an area of $1090 \mathrm{ha}$ is situated $22 \mathrm{~km}$ from Rajkot in semi-arid Saurashtra region, India (Figure 1). The annual rainfall at Rajasamadhiyala during 2002-04 was 419,709 and $490 \mathrm{~mm}$ respectively with a mean annual rainfall of $539 \mathrm{~mm}$. Soils in the watersheds are shallow to medium deep black soils (inceptisols) and formed on hard rock bed. The Deccan basalt trap being a volcanic consolidated rock unit does not have a well-defined aquifer system due to lack of primary porosity. The soil depth ranges from $0.15 \mathrm{~m}$ to $1.25 \mathrm{~m}$. Detailed analysis of surface soil samples collected from different locations by adopting stratified sampling method (Sahrawat et al., 2007) in the watershed in 2004 revealed that these were clay loam to loamy soil. Moisture at field capacity (1/3 bar) ranged from 24.8 to 34.7 per cent (mean 29.9 per cent), and wilting point (15 bar) from 16.6 to 23.1 per cent (mean 20.2 per cent). Plant available moisture of soil ranged from 8.0 to 12 per cent. These soils were severely deficient in boron, zinc and sulphur along with nitrogen and medium for available phosphorus content.

Groundnut and cotton are the predominant crops grown in the watershed area. Other crops include wheat, pearl millet, sorghum, vegetables, maize, pigeonpea, sugarcane, cumin and lucerne fodder crop. Due to additional availability of water in wells, farmers are now able to grow vegetable crops during summer. Mostly the farmers with large families prefer to grow vegetables, as the crops need timely availability of human labor to harvest and encash the market potential.

\section{Shekta Watershed}

Shekta watershed located in Shevgaon tehsil of Ahmednagar district of Maharashtra, India lies partly in the upper hills section of Sahyadris. The watershed lies between $19^{\circ} 05^{\prime} \mathrm{N}$ longitude and $74^{\circ} 55^{\prime}$ 'E latitude. About 675.6 ha out of 1052.38 ha of cultivable land is rain-fed in selected watershed spreading mainly in three villages viz., Shekta, Paragon and Ladgalgaon. Watershed development project was implemented between 1997 and 2004 based on 'ridge to valley concept' for treatment of the catchment with appropriate soil and water conservation measures carried out with active participation of stakeholders through community based organization. The ridge to valley approach is to identify an area and first look at the forest and the hilly regions, in the upper water catchments wherever possible. The purpose of this approach is that all activities required to restore the health of the catchment area by reducing the volume and velocity of surface run-off, including regeneration of vegetative cover in forest and common land, afforestation, staggered trenching, contour and graded bunding, bench terracing etc (Government of India, 2008). The whole Ahmednagar district falls in the semi-arid zone of rain shadow region of Sahyadris and received $465 \mathrm{~mm}$ average annual rainfall during 1990-2004. The area receives all of its annual precipitation from the southwest monsoon. Rainfall starts in first week of June and gets over by beginning of October. The rainfall varied from $338-731 \mathrm{~mm}$ during 1990 to 2004 . The highest rainfall was recorded in 1990 while the lowest in 1994.

The watershed has a South to North slope and the upper catchment comprises moderates slope ( 3 to 7 per cent), middle catchment steep slope ( 7 to 25 per cent) and lower catchment comprised of gentle slope (less than 5 per cent). The texture of soil is clay to sandy clay and the $\mathrm{pH}$ ranges from 7.5 to 8.2 with low organic carbon content. Soil depth varies from $7.5 \mathrm{~cm}$ to 45 $\mathrm{cm}$ and soils are formed over a soft murram layer over a hard rock. Murram is a rocky material found near earth surface is a type of laterite characterized by acidic soil and low nutrient and water holding capacity, which represents hard layer of the soil.

\section{Data Collection and Analyses}

The study is based on primary data collected from two microwatersheds in Indian semi-arid tropics by applying combination of methods such as socio-economic, agronomic and hydrological. Information on the economic factors was collected individually by administering the interview schedule to the respondents. Farmers were selected based on stratified random sampling method in order to collect data in these watersheds. The sampling of data covered about 20 per cent of farmers without double count- 


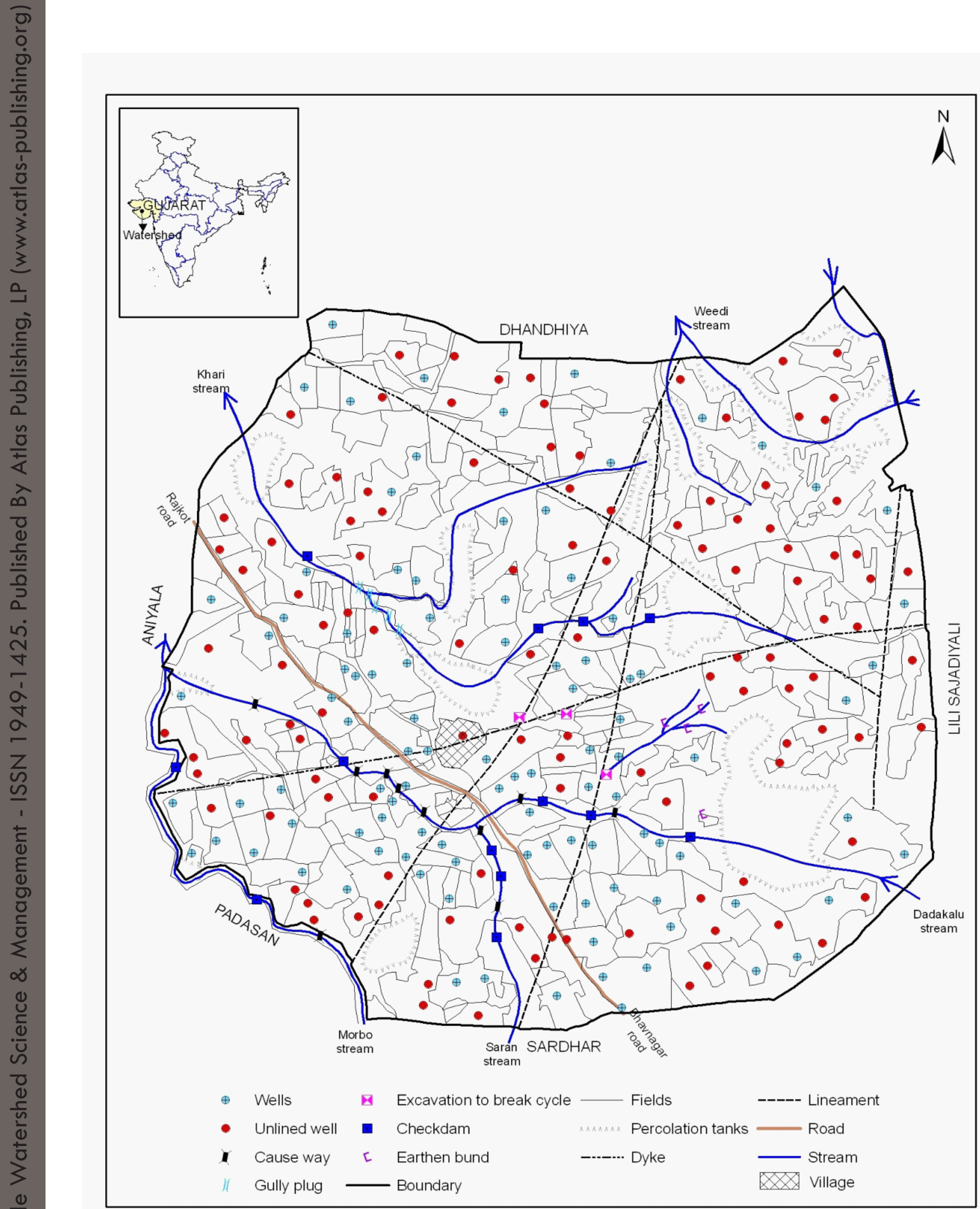

Figure 1. Map of Rajasamdhiyala micro-watershed, Gujarat, India. 
ing of their land holding in the watershed villages. The multifunctions of watershed development such as soil conservation, moisture, improvement and maintenance of fertility status of the soil (Sikka et al., 2000; Sastry et al., 2002; Ramasamy and Palanisami, 2002; Palanisami and Suresh Kumar, 2004; AFC, 2001 ; Sreedevi et al., 2007; Pathak et al., 2006) have been addressed through hydrological and soil related data which were obtained through different survey and measurements. The storage capacity of water harvesting structures (water harvesting refers to collection and storage of natural precipitation and also other activities aimed at harvesting surface and groundwater, prevention of losses through evaporation and seepage and all other hydrological studies and engineering interventions aimed at conservation and efficient utilization of the limited water endowment of a physiographic unit, such as a watershed) was quantified through detailed contour survey and measurement. For the water filled structures, capacity was measured by recording the area under submergence up to outlet/crest level and depth of the water was measured at several places across the cross section to calculate the volume of water stored in the structures. The quantum of water harvested naturally and through watershed interventions was computed for different rainfall conditions. The net quantity of water, which additionally percolated through interventions, was computed by taking into account all the watershed interventions in these watersheds. The duration of water, which remained in the structure, and area it covered, varied in different conditions of rainfall. Hence, appropriate assumptions were made for the duration for which water was retained in water harvesting structures covering 100 per cent area at full reservoir level (FRL) and decreased to 60 per cent of area in later days. Three percolation rates of $20 \mathrm{~mm}$ day-1, $15 \mathrm{~mm}$ day- 1 and $10 \mathrm{~mm}$ day- 1 were adopted for different periods of monsoon, to take into account the decreased percolation as substrata reaches saturation point. Considering the terrain topography, the natural recharge percentage has been considered as 15 per cent of total precipitation for all the three rainfall conditions based on the values suggested for Saurashtra region (Patel, 2005). Soil samples have been collected randomly in a specific field and analysed, these data are means of 8 samples. In a particular watershed, soil profile pits were

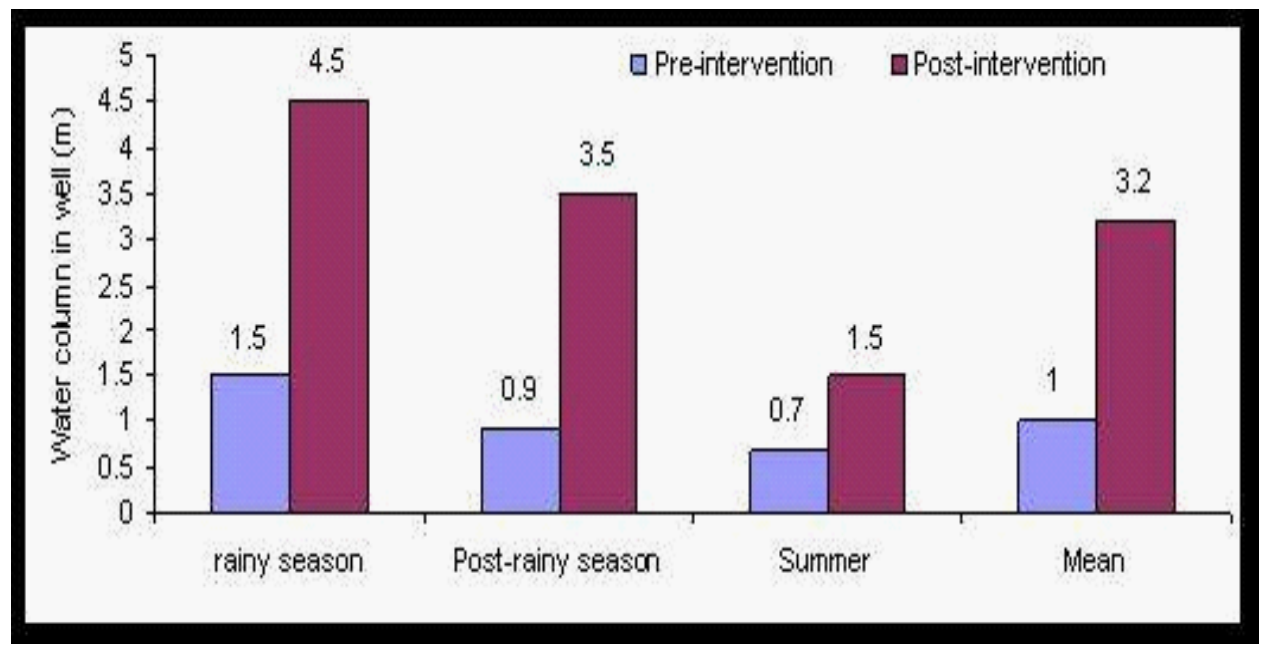

Figure 2. Effect of watershed interventions in improving the groundwater levels in Shekta watershed.

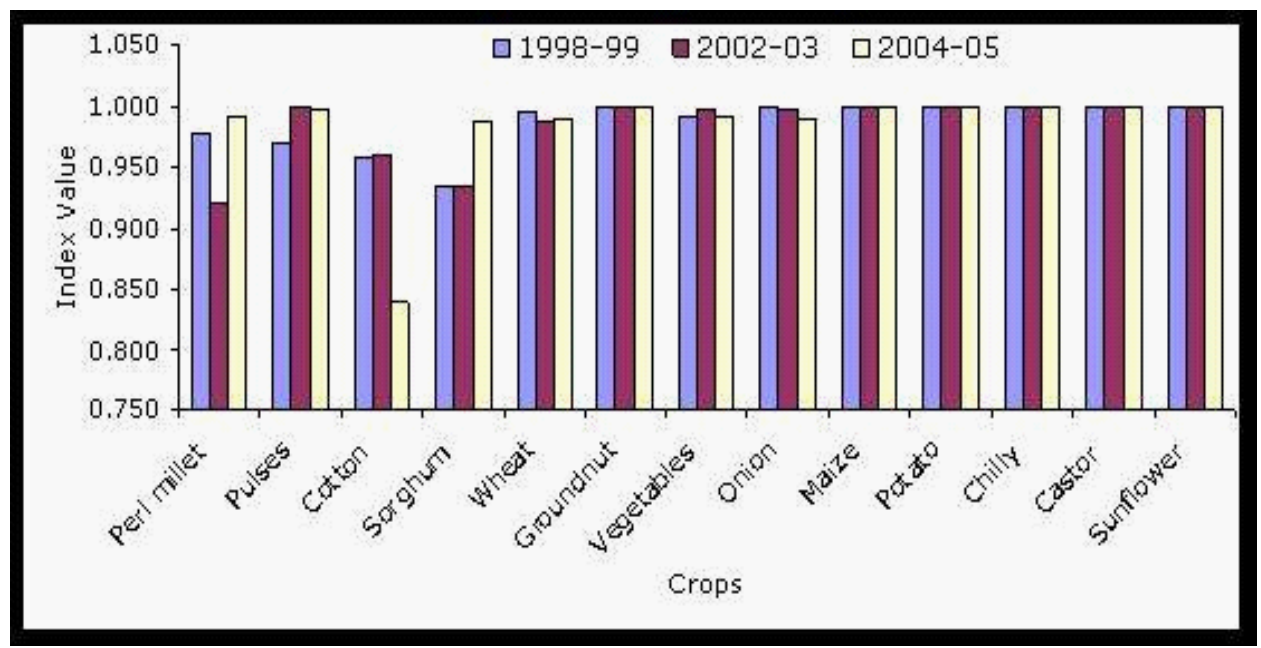

Figure 3. Diversification index over a period of time in Shekta watershed. 


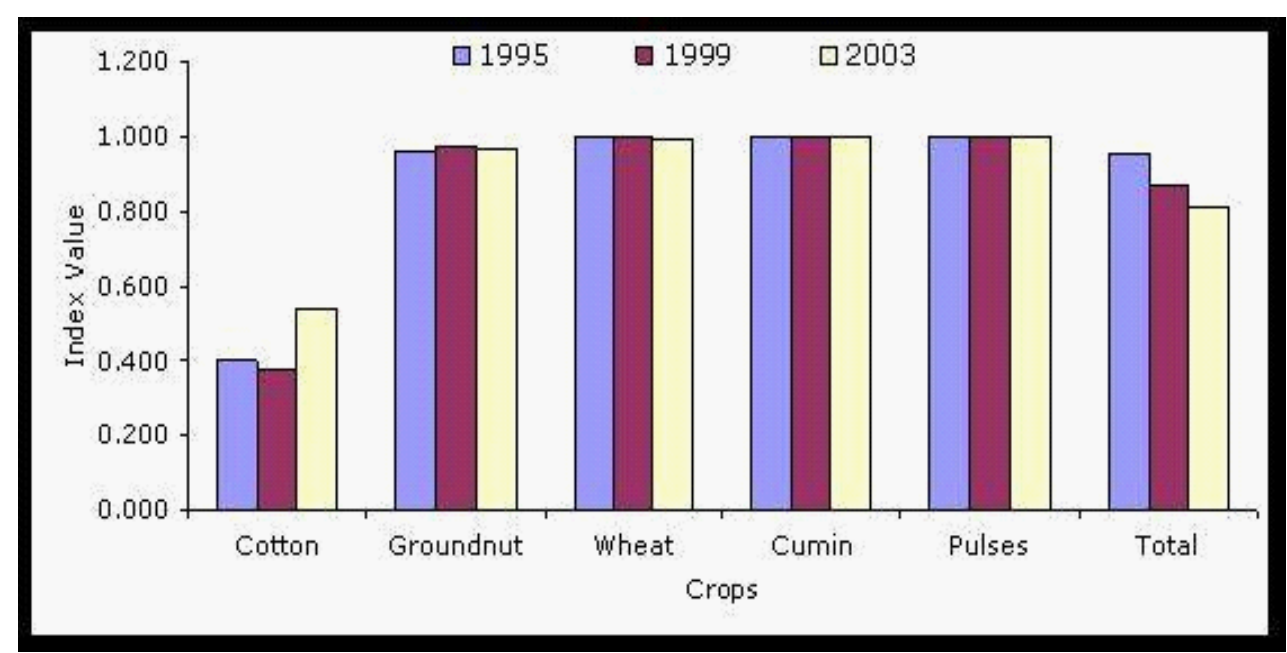

Figure 4. Diversification index over a period of time in Rajasamadhiayala watershed.

dug to study soil properties on toposequence.

The economic dimension is also incorporated, wherever necessary, in terms of benefit-cost analysis to reflect the feasibility of environmental and ecological benefits achieved in the proiect. Crop diversification, as a result of increasing soil fertility and water availability, over a period of time is measured using two different indices viz., Hirschman-Herfindal diversification index and Simpson index (Sreedevi et al., 2006, 2008). The diversification index, calculated as $\mathrm{DI}=1-\mathrm{H}$, where $\mathrm{H}$ is Hirschman-Herfindal Index, measured by , Pit being the value of production at 2002-03 prices of the ith crop in year t. On the other hand, the Simpson index, where $\mathrm{Pi}$ is the proportion of area under ith crop was used. The higher diversity index indicates higher magnitude of diversification in production patterns suggesting ability to reduce risks associated with failure of one crop due to variable rainfall and with other biotic and abiotic factors. While lesser indicate concentration of crops because of specialization. The cropping intensity refers to raising of a number of crops from the same field during one agriculture year. It can be expressed as:

Cropping intensity $=($ Gross Cropped Area/Net Sown Area) $X$ 100

Thus, higher cropping intensity means that a higher portion of the net area is being cropped more than once during one agricultural year. The gross output of each crop for different years is valued at constant (2003-04 farm harvest) prices and in order to be summed up to arrive at the aggregate value of crop production.

\section{Results and Discussion}

Watershed interventions have contributed for livelihood security and the ecosystem sustainability. The process of development was through intense community involvement, which helped the capacity building and awareness of stakeholders in the watershed area. During the watershed development phase the involvement of the community was impressive that has contributed greatly for natural resource management and livelihood security. The major environmental and ecological benefits accrued from watershed management are through soil and water conservation activities.

\section{Soil Conservation and Water Harvesting}

Various soil and water conservation measures viz., contour bunding, farm bunding, earthen bunding and stone bunding were taken up to prevent the soil erosion and in-situ conservation of rainwater covering an area of about 789 ha in Shekta and 755 ha in Rajasamadhiyala watersheds (Table 1). To harvest the excess runoff water and to control erosion of major gullies check weirs and check dams were constructed and strengthening the nala bunding was done. Apart from the in-situ rainwater conservation through various soil conservation measures, runoff water harvesting structures of $28950 \mathrm{~m} 3$ in Shekta and 854261

Table 1. Details of water harvesting, storage capacities, average unit cost and soil conservation structures in Shekta and Rajasamadhiyala watersheds.

\begin{tabular}{|l|c|c|c|}
\hline Water harvesting structures & $\begin{array}{c}\text { No. of structures/area } \\
\text { covered (ha) }\end{array}$ & $\begin{array}{c}\text { Total storage } \\
\text { capacity }\left(\mathbf{m}^{3}\right)\end{array}$ & $\begin{array}{c}\text { Total cost } \\
\text { (US\$) }\end{array}$ \\
\hline Shekta watershed & & 2730 & 2833 \\
\hline Check dam & 1 & 10220 & 18743 \\
\hline Repair of nala bund & 16 & 16000 & 3836 \\
\hline $\begin{array}{l}\text { Continuous contour trenches } \\
\text { (CCT), water absorption trench } \\
\text { (WAT), aforestation }\end{array}$ & 4 & NA & 24093 \\
\hline $\begin{array}{l}\text { Contour bunding (CB), farm } \\
\text { bunding (FB), stone bunding } \\
\text { (SB), gully plugs (GP) }\end{array}$ & $157^{\#}$ & & \\
\hline & & NA & 47335 \\
\hline Check dam & $632^{\#}$ & 64410 & 24333 \\
\hline Causeway-cum-check dam & 13 & 45855 & 28532 \\
\hline Percolation tank & 10 & 731811 & 325249 \\
\hline Farm pond & 6 & 4800 & 2560 \\
\hline Earthen bund & 3 & 7385 & 1149 \\
\hline
\end{tabular}

Note: \# Area in ha; NA = Not Applicable 
m3 net storage capacity in Rajasamadhiyala were created in these watersheds. In both the areas the watershed interventions brought significant changes in soil and water conservation activities.

The implementation of soil and water conservation interventions resulted in reduction in runoff and rise in the groundwater level in benchmark watersheds. The different form of water harvesting structures, the storage capacity and the cost of these structures varies significantly (Table 1). Storage capacity of water harvesting structures ranged from $2730 \mathrm{~m} 3$ to $16000 \mathrm{~m} 3 \mathrm{in}$ Shekta watershed and $4800 \mathrm{~m} 3$ to $731811 \mathrm{~m} 3$ in Rajasamadhiyala watershed. The unit cost of these structures varied from Rs. 7 (US\$ 0.15) and Rs. 83 (US\$ 1.84) m-3 of water stored in Rajasamadhiyala and Shekta watersheds respectively. The highest unit cost per $\mathrm{m} 3$ is found in check weir. The Continuous Contour Trenches (CCTs) and water absorption trenches were quite cost effective (Rs. 30 (US\$ 0.66) m-3 water stored) and in addition also served as traps for soil erosion. However, unless strict technical guidelines are followed while constructing the CCTs, they get filled with soil and also breached, causing severe erosion.

These benefits were obtained with the total investment of Rs. 16.25 millions (US\$ 0.36 million) in Rajasamadhiyala and Rs. 0.93 million (US\$20670) on rainwater harvesting structures in Shekta watershed. In Shekta watershed, 620 ha land was treated for soil and water conservation which covered 58.8 per cent of total watershed area which is distinctly different from normal watershed programs, where large proportion of budget is spent on rainwater structures (Sreedevi et al., 2006). Considering the rainfall in the region and low potential for runoff the approach of in-situ rainwater conservation as against the runoff harvesting was most appropriate. As revealed by the meta-analysis of 636 watershed case studies from different agro ecological zones, watersheds in different rainfall zones need different approach. The principle of one size fits all approach generally adopted by watershed program resulted in low benefit-cost ratios as well as impact measured with other parameters being far lower in low rainfall $(<700 \mathrm{~mm}$ ) zone than the $700-1000 \mathrm{~mm}$ rainfall zones (Joshi et al., 2008).

The storage capacity of check dam/causeway-cum-check dams ranged from 1000-15000 m3, benefiting 128 open wells of 112 farmers with an area of 281 ha in Rajasamadhiyala watershed. The percolation tank was built with storage capacity of $731811 \mathrm{~m} 3$, which served the area of 461 ha with 149 wells and benefited 101 farmers. The immediate benefit of water harvesting structures is the increasing recharging capacity of wells. This provided an opportunity to small and marginal farmers to access groundwater for irrigation purposes and increase the land and water productivity with minimizing the cost of production.

The storage capacity of all the water harvesting structures in Rajasamadhiyala watershed was $79 \mathrm{~mm}$ or about 16 per cent of mean annual rainfall (mean of 20 years rainfall is $503 \mathrm{~mm}$ ). This is equivalent to the potential runoff during a normal rainfall year in the watershed with an average unit cost of construction of Rs. 19 (US\$ 0.42) per m3. Considering the percolation/ seepage and evaporation from the water harvesting structures, about 40 per cent of mean annual rainfall can be harvested.
Despite this fact, during normal rainfall years, 2-3 times overflow takes place from the structures. In addition, downstream watersheds get water through seepage/base flow from these structures; hence they are not affected by reduction in surface runoff to their watershed due to the construction of water harvesting structures in the upstream watersheds coming from upstream drains/streams. In addition to this, the downstream watersheds have also benefited by good groundwater recharge due to water harvesting structures constructed in the upstream watersheds. This aspect of subsurface water flows and runoff benefiting the down stream villages in spite of huge rainwater harvesting need to be considered along with geological formation.

\section{Groundwater Recharge}

Groundwater recharge is the indirect ecosystem service realized through watershed intervention. Due to the water harvesting and various soil and water conservation structures, there is a significant improvement in the groundwater status (Table 2). The groundwater recharge scenario can be explained more evidently in terms of functional wells, duration of pumping hours and status of water column in wells. The density of wells and functioning rate is increasing substantially due to water availability. In Shekta watershed, there was an increase of 48 per cent in the total number of wells and 51 per cent increase in the seasonally functional wells, while there was a drastic increase of 223 per cent wells functioning during 4-8 months in a year and 128 per cent increase was observed in perennially functioning wells (812 months in a year). There was a sharp decrease in the number of non-functioning wells (about 83 per cent decrease) as a result of water conservation measures.

In Rajasamadhiyala, open wells have been increasing at the rate of 20.8 per cent per annum between 1995 and 2004 while bore wells increased at 96.1 per cent during the same period. In 1995, 255 wells existed with very poor yield with an average water column of $5.9 \mathrm{~m}$, but due to watershed intervention the number of wells increased to 308 wells with mean water column

Table 2. Pre and post-interventions scenario of total water requirement for crop irrigation and total groundwater recharge for good, average and lean rainfall years in Rajasamadhiyala.

\begin{tabular}{|c|c|c|c|c|c|c|}
\hline \multirow[t]{2}{*}{$\begin{array}{l}\text { Rainfall } \\
\text { scenario }\end{array}$} & \multicolumn{3}{|c|}{$\begin{array}{l}\text { Pre-intervention groundwater (GW) } \\
\text { scenario }(\mathrm{mm})\end{array}$} & \multicolumn{3}{|c|}{$\begin{array}{l}\text { Post-intervention groundwater (GW) } \\
\text { scenario }(\mathrm{mm})\end{array}$} \\
\hline & $\begin{array}{l}\text { Total GW } \\
\text { recharge }\end{array}$ & $\begin{array}{l}\text { Total water } \\
\text { requirement } \\
\text { for irrigation }\end{array}$ & $\begin{array}{l}\text { NetGW } \\
\text { balance }\end{array}$ & $\begin{array}{l}\text { Total GW } \\
\text { recharge }\end{array}$ & $\begin{array}{l}\text { Total water } \\
\text { requirement } \\
\text { for irrigation }\end{array}$ & $\begin{array}{l}\text { NetGW } \\
\text { balance }\end{array}$ \\
\hline Good & 123 & 99 & 29 & 364 & 212 & 155 \\
\hline Average & 92 & 79 & 13 & 287 & 165 & 122 \\
\hline Lean & 37 & 39 & .1 & 98 & 87 & 11 \\
\hline
\end{tabular}

Note: Results presented for Good, Average and Lean rainfall scenarios is based on the Indian Meteorological Department (IMD) classification of Excess, Normal and Deficit years respectively. According to the IMD classification: rainfall less than $20 \%$ of the long term average = Lean; rainfall between $-20 \%$ to $+20 \%$ of the long term average = Average; rainfall greater than $20 \%$ of long term average $=$ Good (Indian Meteorological Department, Pune, India; http://www.imdpune.gov.in). 
of $10.4 \mathrm{~m}$. The average depth of wells in the watershed is $18 \mathrm{~m}$. The increase in water column was $6.6 \mathrm{~m}, 5.3 \mathrm{~m}$ and $1.3 \mathrm{~m}$ during rainy, post-rainy and summer seasons respectively. Overall there has been an increase of $4.4 \mathrm{~m}$ of water column in 2004, as compared to that of 1995 . The average pumping duration of 5.25 hours per day in 1995 has increased to $10.4 \mathrm{~h}$ per day in 2004. This revealed that there has been a net increase of $5.2 \mathrm{~h}$ per day of pumping. The increase in pumping duration in rainy season was $9.5 \mathrm{~h}$ per day, and in summer $0.75 \mathrm{~h}$ per day.

The status of groundwater in terms of water column in wells during pre-interventions of watershed program in Shekta watershed was $1.5 \mathrm{~m}$ in rainy season, $0.90 \mathrm{~m}$ in post-rainy season and $0.65 \mathrm{~m}$ in summer, while after watershed interventions, water column in wells during rainy season was $4.5 \mathrm{~m}$, during post-rainy season was $3.5 \mathrm{~m}$ and in summer was $1.5 \mathrm{~m}$ in Shekta watershed (Figure 2). An average water column of wells throughout the year was $1.02 \mathrm{~m}$ before watershed intervention whereas after watershed interventions the water column in the wells was 3.17 $\mathrm{m}$, which is about 211 per cent increase in the water column.

The watershed intervention brought phenomenal changes in groundwater recharge. In Rajasamadhiyala, total groundwater recharge has increased by three-folds in different rainfall situations (Table 2). Shekta watershed also showed impressive improvements in groundwater levels due to watershed intervention (Figure 2). Water requirement has doubled after the interventions due to increased cropping intensity and change in cropping pattern. In sum, the increased availability of water in wells has brought significant changes in land use pattern, production and productivity. This in turn, strengthened livelihood security.

\section{Land use Pattern, Production and Productivity}

The increased availability of water in wells tremendously increased the area under irrigation (Table 3). The total irrigated area increased by 58 per cent in Rajasamadhiyala and 92.6 per cent in Shekta watersheds. Importantly, the area under rainfed has declined about 14 per cent and 43 per cent in Shekta and Rajasamadhiyala watersheds respectively. This indicates that the groundwater availability is significantly contributing to

Table 3. Land use pattern in watershed area (in ha).

\begin{tabular}{|c|c|c|c|c|c|c|}
\hline \multirow{3}{*}{ Land use } & \multicolumn{3}{|c|}{ Shekta Watershed } & \multicolumn{3}{|c|}{ Rajasamadhiyala Watershed } \\
\hline & Before watershed & After watershed & & efore watershec & fter watershed & \\
\hline & $\begin{array}{l}\text { intervention } \\
(1998-99)\end{array}$ & $\begin{array}{l}\text { intervention } \\
(2004-05)\end{array}$ & $\begin{array}{l}\text { Change } \\
(\%)\end{array}$ & $\begin{array}{l}\text { intervention } \\
(1995)^{*}\end{array}$ & $\begin{array}{l}\text { intervention } \\
(2003)\end{array}$ & $\begin{array}{l}\text { Change } \\
(\%)\end{array}$ \\
\hline Rain-fed area & 675.6 & 581 & .14 .0 & 372 & 212 & -43.0 \\
\hline Irrigated area & 158.79 & 306 & 92.6 & 356 & 551 & 54.8 \\
\hline Pasture/grazing & & & & & & \\
\hline area & 0 & 32.68 & 100.0 & 64 & 54 & .15 .6 \\
\hline Cultivable & & & & & & \\
\hline wasteland & 85.39 & 0.0 & .100 .0 & 283 & 258 & -8.8 \\
\hline Govt. & & & & & & \\
\hline forest/village land & 132.6 & 132.6 & 0.0 & 14 & 14 & 0.0 \\
\hline Total & 1052.38 & 1052.38 & NA & 1089 & 1089 & NA \\
\hline
\end{tabular}

Note: * Due to non-availability of adequate base-line data, we consider 1995 as the pre-intervention period, although the watershed program started in this area in 1983. NA = Not Applicable. the net irrigated area after the watershed intervention. There was considerable increase in the area of pasture/grazing land in Shekta watershed whereas about 16 per cent decline in Rajasamdhiyala watershed was observed. Similarly, cultivable wasteland has come down drastically in Shekta watershed after the watershed intervention indicating that the irrigation availability has enabled farmers to bring erstwhile wasteland under cultivation. Marginal change can be observed in terms of reduction in fallow land in Rajasamadhiyala (Table 3). All in all, there was a significant change in terms of land use pattern in both the watersheds. Importantly, large amount of area has been brought under irrigation owing to availability and access to groundwater, which was possible mainly through water harvesting structures.

To examine the efficiency and potential water and soil conservation activities on crop production, increased crop yields in watershed villages; area, productivity and yields of various crops have been analyzed. Watershed interventions provide an opportunity for change in cropping pattern and it was observed that the farmers benefited from the change in cropping pattern and high cropping intensity during watershed development programs in both the watersheds.

In Rajasamadhiyala, in rainy season, the area under maize crop increased sharply (55.56 per cent) followed by vegetables (44.83 per cent) and pearl millet (37.5 per cent) from 1995 96 to 2003-04. Although there was a considerable increase in the productivity of groundnut (1 19.4 per cent), but the area increased by 13 per cent during the same period. In Rabi, the per cent change in the area of wheat cultivation was found highest (764 per cent) followed by cumin (363 per cent). The area under pulses decreased by 20 per cent in 2003-04 compared to $1995-96$ as the farmers moved to high-value crops with increased water availability. Pulses are generally cultivated as rain-fed crops on poor quality soil. During summer, the area of vegetables was found substantial increase (175 per cent) followed by pulses+groundnut (157.14 per cent) and fodder (100 per cent). Significant gains in crop productivity ranging from 15.7 per cent in vegetables to 119 per cent in groundnut crop were recorded in the watershed. The productivity of crops grown in rainy and post-rainy seasons was increased along with the area under cultivation.

Similarly, in Shekta watershed, during the watershed development program, the area under pearl millet increased sharply from 148 ha in $1998-99$ to 291.24 ha in $2002-03$ by 96.8 per cent but again it has come down to 113.15 ha $(61$ per cent decline) in 2004-05 largely due to cultivation of high-value crops by the farmers with increased water availability (Table 4). The area under pulses and sorghum crops declined sharply about 68.75 per cent and 43.10 per cent respectively over the period. The area under cotton and wheat which are cash crops increased by 152.9 and 90.9 per cent respectively while the area under groundnut increased marginally by 24.3 per cent during the same period. The area under vegetables increased sharply by 125 per cent and other new vegetables like onion, potato, chilly were added up during the same period.

These results are in conformity with the earlier findings that with increased water availability in the watershed due to rain- 
Table 4. Change in cropping pattern in Shekta watershed (area in ha).

\begin{tabular}{cccccc}
\hline Major crops & $\mathbf{1 9 9 8 - 9 9}$ & $\mathbf{2 0 0 1 - 0 2}$ & $\mathbf{2 0 0 2 - 0 3}$ & $\mathbf{2 0 0 3 - 0 4}$ & $\mathbf{2 0 0 4 - 0 5}$ \\
\hline Pearl millet & 148 & 200 & 291.2 & 151.4 & 113.2 \\
Pulses & 168.6 & 25 & 12.5 & 16.5 & 52.7 \\
Cotton & 201.6 & 150 & 207 & 469.3 & 509.8 \\
Sorghum & 250 & 280 & 265 & 195 & 142.2 \\
Wheat & 70.5 & 105 & 115 & 125 & 134.6 \\
Groundnut & 22.5 & 25 & 17.2 & 25.5 & 29.7 \\
Vegetables & 90 & 12 & 59.5 & 131.9 & 120.6 \\
Onion & 0 & 8 & 55 & 136.3 & 124.8 \\
Maize & 5.9 & 0 & 8.3 & 11.6 & 21.9 \\
Potato & 0 & 0 & 4 & 10 & 0 \\
Chilly & 0 & 0 & 2.5 & 5.4 & 8.9 \\
Castor & 0 & 0 & 0 & 0 & 5.2 \\
Sunflower & 7 & 10 & 0 & 0 & 8.4 \\
Sugarcane & 13.3 & 0 & 0 & 0 & 0 \\
Cropping & 95 & 79 & 100 & 124 & 123 \\
intensity (\%) & & & & & \\
\hline
\end{tabular}

water conservation and harvesting, area under low-value crops decline and farmers shift towards growing high-value crops as observed in Adarsha watershed, Kothapally in Andhra Pradesh (Wani et al., 2003a). The long-term crops have been absolutely stopped in these watersheds that indicates that farmers are very keen of short-duration high value crops, which provide continued income compared to perennial crops. This also indicated increased awareness amongst farmers to use available water resources efficiently for enhancing incomes.

The cropping intensity, one of the indicators to measure agriculture efficiency, was 164 per cent in 2003 in Rajasamadhiyala and 123 per cent in 2004-05 in Shekta watershed. The cropping intensity increased slightly by 29.47 per cent from 199899 to 2004-05 in Shekta watershed and the value for change in cropping intensity during 1995 to 2003 in Rajasamadhiyala was lower by 50 per cent as against to 66 per cent observed in other watershed programs in India (Joshi et al., 2005). This could be largely due to the initial increase in cropping intensity during 1983 to 1995 period could not be captured owing to lack of baseline data in 1983.

\section{Area, Production and Water Harvesting Structures}

Water harvesting structures have provided an opportunity to expand area under irrigation and increased production per unit of water extraction. The results on relation between the areas irrigated and production due to the water harvesting structure during 1995, 1999 and 2004 revealed that the area and the production improved significantly in Rajasamadhiyala watershed (Table 5). Total production includes cereals (wheat, pearl millet, sorghum and maize), pulses (Mungbean, pigeaonpea, blackgram and chickpea), oil seeds (groundnut, and sesame), vegetables (brinjal, cluster bean, chilly, coriander and tomato), cash crops (cotton, sugarcane and cumin), green fodder (lucerne and maize). During initial period of interventions (i.e., 1995) the production per unit storage capacity of water harvesting structure was $4.9 \mathrm{~kg} \mathrm{~m}-3$ of water with an average production per unit area of $4443 \mathrm{~kg}$ ha-1. During 1999, the production was $6.6 \mathrm{~kg} \mathrm{~m}-3$ with an average yield of $5270 \mathrm{~kg} \mathrm{ha-1.} \mathrm{Dur-}$
Table 5. Water harvesting structures and its impact on area and production in Rajasamadhiyala.

\begin{tabular}{ccccccc}
\hline Year & $\begin{array}{c}\text { Rainfall } \\
(\mathrm{mm})\end{array}$ & $\begin{array}{c}\text { WHS storage } \\
\text { capacity } \\
\left(\mathrm{m}^{3}\right)\end{array}$ & $\begin{array}{c}\text { Irrigated } \\
\text { Area }(\mathrm{ha})\end{array}$ & $\begin{array}{c}\text { Yield } \\
\left(\mathrm{Kg} \mathrm{ha}^{-1}\right)\end{array}$ & $\begin{array}{c}\text { Production } \\
(\mathrm{t})\end{array}$ & $\begin{array}{c}\text { Production }(\mathrm{kg} \\
\mathrm{m}^{3} \text { of storage } \\
\text { capacity) }\end{array}$ \\
\hline 1995 & 307 & 699510 & 769 & 4443 & 3417 & 4.9 \\
1999 & 311 & 806058 & 1005 & 5270 & 5296 & $6.6(35)$ \\
& & & 1218 & 5434 & 6619 & $7.7(59)$ \\
2004 & 503 & 855461 & $19)$ & & \\
& & & & $(22)$ & & \\
Mean & 510 & 792389.3 & 1001.9 & 5106 & 5173.5 & $6.5(33)$ \\
SD & 185.4 & 51674.1 & 145.3 & 344.0 & 1042.4 & 0.91 \\
CV (\%) & 36.3 & 6.5 & 14.5 & 6.7 & 20.2 & 14.1 \\
\hline
\end{tabular}

Note: Values in parentheses are the percentage increase over 1995.

ing $2004,7.7 \mathrm{~kg}$ production $\mathrm{m}^{-3}$ water stored with an average yield of $5,434 \mathrm{~kg} \mathrm{ha}^{-1}$ was reported. The overall production of $6.5 \mathrm{~kg} \mathrm{~m}^{-3}$ of storage capacity with an average yield of 5124 $\mathrm{kg} \mathrm{ha}^{-1}$ was observed, which is about 33 per cent increase in production $(\mathrm{kg})$ per unit storage capacity $\left(\mathrm{m}^{3}\right)$, while there was a 15 per cent increase in yield $(\mathrm{kg})$ per unit area irrigated (ha) in 2004 over 1995. Increased production per m3 of water storage capacity clearly suggest that with increased water availability farmers invested in other productivity enhancement interventions which also resulted in increased water use efficiency as indicated by Rockstrom et al. (2010).

The impact of water harvesting structure on the expansion of area under irrigation and productivity is substantial considering its contribution to the livelihood security and environmental sustainability. The irrigated area expansion due to water availability provides an opportunity to diversify the cropping system as per the market structures as well as the demand. The crop diversification would allow farmers to improve their wealth condition by making profit out of diversification which otherwise would not have been possible.

\section{Crop Diversification}

Many environmental benefits are reflected in terms of changing cropping pattern and increasing income levels. The water and soil conservation measures enabled farmers to generate farm income within short period through crop intensification and diversification. In both watersheds, the crop diversification was observed a mixed trend. During project period significant changes were observed in Shekta and Rajasamadhiyala watersheds irrespective of hydro-geological differences. After watershed interventions, more numbers of crops were cultivated and crops like sugarcane were abandoned but high-value and water efficient crops were cultivated. The increasing availability of groundwater has influenced cultivation of short-term high-value crops. Therefore, the degree of diversification was high after watershed interventions. However, there is mixed fluctuation of diversification observed during the watershed development program (Table 6), which happens, considering the external market- 
Table 6. The value and growth of total production in Rajasamadhiyala watershed (in US dollars).

\begin{tabular}{ccccccccc}
\hline \multirow{2}{*}{ Year } & Cotton & Groundnut & Wheat & Cumin & Pulses & production & CGR (\%) \\
\hline \multirow{4}{*}{1995} & 341878 & 86904 & 4189 & 7648 & 1004 & 441621 & From \\
& $(77.41)$ & $(19.68)$ & $(0.95)$ & $(1.73)$ & $0.23)$ & $(21.00)$ & $1995-99$ \\
& {$[0.401]$} & {$[0.961]$} & {$[1.00]$} & {$[1.00]$} & {$[1.00]$} & {$[0.956]$} & 11.39 \\
& 600886 & 116250 & 18628 & 20831 & 777 & 757372 & From \\
1999 & $(79.34)$ & $(15.35)$ & $(2.46)$ & $(2.75)$ & $(0.10)$ & $(36.00)$ & $1999-03$ \\
& {$[0.371]$} & {$[0.976]$} & {$[0.999]$} & {$[0.999]$} & {$[1.00]$} & {$[0.871]$} & 3.58 \\
& 612374 & 165832 & 70729 & 52885 & 1156 & 902975 & From \\
2003 & $(67.82)$ & $(18.37)$ & $(7.83)$ & $(5.86)$ & $(0.13)$ & $(42.96)$ & $1995-03$ \\
& {$[0.54]$} & {$[0.966]$} & {$[0.994]$} & {$[0.997]$} & {$[1.00]$} & {$[0.816]$} & 18.92 \\
\hline
\end{tabular}

Note: Figure in parentheses indicates percentage of value of particular crops over total value of all crops. Figures in square brackets are the values of diversification index. CGR: Compound growth rate.

\section{ing factors.}

The diversification index has revealed many interesting facts (Table 6). In Rajasamadhiyala, the index of cotton declined in 1999-2000 but sharply increased in 2003-04, which indicates higher diversification rather than concentration in 1999-2000. The index of groundnut remains stable in 1999-2000 the crop was diversified marginally but in 2003-04 it was concentrated. The index of both wheat and cumin crops declined continuously over a period, which indicated the concentration of crops during the same period of time largely due to higher market prices. The diversification index in the output mix declined continuously from 1995-96 to 2003-04, which indicated higher concentration of mixed crops on production pattern rather than diversification. The results reveal that due to availability of water, crops like vegetables and fodder are grown instead of cereal crops.

The diversification index for each crop examines their level of spread resulting in crop diversification and concentration (Figures 3 \& 4). The figure 4 indicates that from 1995-96 to 1999 2000 with the highest value of diversification index the pulse crop remained constant while there was high concentration in cotton in the watershed area. However, from 1993-94 to 200304 the scenario of cropping pattern changed sharply and the cotton crop further diversified and groundnut dominated once again. It is interesting to note that the index of pulse crop remained constant indicating that there was neither diversification nor concentration over a period of time. This could be because of a stable market price for pulses as well as need for consumption as a source of protein.

The total value of output of all crops increased at a compound growth rate (CGR) of 11.39 per cent during 1995-96 to 1999-2000, but CGR declined sharply to 3.58 per cent from 1999-2000 to 2003-04. These results indicate that initial effects of irrigation resulted in higher CGR. However, to maintain similar CGR necessary interventions to bring in enhanced water use efficiency are needed. Overall, from 1995-96 to 200304 the CGR of production of all crops increased by 18.92 per cent (Table 6). In terms of value of production in constant prices in 1999-2003, Rajasamadhiyala recorded cotton receiving Rs. 2750, groundnut Rs 1625, wheat Rs 800, cumin Rs 6008 and pulses Rs 1500 per quintal.

There was mixed fluctuation of diversification observed during the watershed development program in Shekta watershed (Figure 3). The figure demonstrated more fluctuation in sorghum crop towards diversification followed by pearl millet, wheat and onion while other crops maintained stability. The crops like maize, potato, chilly, castor and sunflower remained constant, resulting in neither diversification nor concentration during specific period of time.

\section{Livestock and Fodder Availability}

The water and soil conservation activities through implementation of watershed development program have produced several positive externalities in strengthening local economy. In this context, livestock has emerged as a major income earning activity. The water availability has triggered year long availability of green fodder for livestock and building resilience in terms of food security for cattle. In Shekta watershed, the fodder availability due to increased water availability resulted in replacement of unproductive 50 per cent of indigenous cows by cross breed cows. The milk production before initiation of watershed program in 1998 was only 250 liters per day but now it has increased by manifold. The fodder availability for each animal from agriculture produce increased constantly from the inception of watershed program. Due to implementation of watershed program, the fodder availability in summer season reached $5+$ per animal, followed by rabi and kharif agriculture produce 1 t each and fodder from forest by 0.5 t per animal respectively.

The area under fodder production during 1998 was only 3.5 per cent of total cultivated area, as there was increase in the availability of water due to watershed interventions the area under fodder also consistently increased, about 18 per cent of total cultivated area in 2004 . The significant increase in the area and productivity of fodder encouraged farmers to replace their local breeds with improved breeds and also increase the livestock production leading to increased milk production.

In Rajasamadhiyala, there is increasing trend in fodder availability between 1995 and 2003. The watershed program has enabled to secure fodder for cattle and thereby increase in milk production. The fodder security increased from 61.14 per cent during 1995 to 102.62 per cent in 1999 and 109 per cent in 2003. Therefore, it is clearly evident that the watershed intervention has brought ecological and economic security along with environmental security in the watershed villages.

\section{Ecological Effects of Watershed Development}

The visible effects of watershed development are many and water availability is an important component, which is possible through construction of water harvesting structures. There were several water and soil conservation measures undertaken to boost agriculture productivity. For the study, the local species was selected with the help of local people and the crop and plant species mix to maintain the biodiversity of the area was carried out. The survival rate of the plants of different species was approximately 80 per cent. This revealed that the 
watershed interventions have positive impact on maintaining ecological balance. The ecological balance can be defined as the condition of equilibrium among the components of a natural community such that their relative numbers remain fairly constant and their ecosystem is stable. Gradual readjustments to the composition of a balanced community take place continually in response to natural ecological succession and to alterations in climatic and other influences.

To support the regeneration of natural resources in the watershed area and maintain the ecological balance forestland was developed through the formations of the local institutions viz., ban on free grazing on treated lands and ban on felling of trees. Land treatments like continuous contour treatment, contour bund, afforestation, etc., have been carried out on the CPRs to improve the productivity of land and to maintain the ecological balance.

There are several measures adopted to minimize land degradations i.e., soil erosion, soil salinity, etc. Major treatments where continuous contour trenching, refilling of these trenches for plantations, gully plugging and repair of farm bunds along with land use measures such as crop cultivation, afforestation, reforestation and agro horticulture and hortipastural etc were undertaken. Under farm and contour bunding the treatment involved repair of existing farm bunds and new bunds along the contour across the slope with interval. The other measures like cultivation of improved grass species such as dinanath, pavana, marvel, stylo were grown in order to protect soil erosion to improve soil status like organic contents of the soil through contour cultivation, cover cropping with pulse on greater slope land, crop rotation, green manuring, mulching, etc.

\section{Conclusions}

The environmental benefits seen in terms of soil and water conservation measures revealed that the watershed intervention was a panacea for water scarcity and land degradation problems in both the watershed areas which suffered early with water scarcity and frequent droughts. Significant changes were observed in areas under irrigation, cropping pattern and intensity along with diversification of crops from traditional to commercial cash crops. The increased water storage capacity has enabled to cover more area under irrigation and enhancing the cropping intensity and productivity of different crops in both the watersheds. All these benefits have demonstrated that the watershed interventions are most suited conservation practices to improve the rural livelihoods system in a more sustainable way.

It is evident that the water and soil conservation activities have triggered for high-value crops, attractive yield rate and hence improved livelihoods. If the present situation to be sustainable, there is need for suitable policies with appropriate incentives for water efficient crops and penalties for growing water inefficient crops and overexploitation of groundwater.

The environmental benefits accrued from watershed development approach are multi-functional and have substantial impact on the community and the ecosystem. An assessment of these benefits may lead to the identification of essential elements in a landscape that have substantial impact on the ecosystem. As we have seen, numbers of subsidiary benefits have been obtained due to their multi-functionality. Soil and water are likely to play a major role in delivering many such environmental benefits that are essential for environmental sustainability and livelihood security. Further, land and water form an important part of the causal chain in any environmental management issue and it is the time that available methods were used to assess and strengthen the resource base. Watershed management proved to be a good entry point to improve livelihoods of people and also to sustain natural resources.

\section{Acknowledgements}

We sincerely thank Mahesh S. Patil, Jayesh Talati, Tushaar Shah and Harshavardhana K Deshmukh for their involvement and valuable contribution at the initial stage of manuscript preparation. We also thank the help of staff of watershed departments, village watershed committee members and farmers for providing necessary inputs during the field visits.

\section{References}

Agricultural Finance Corporation (AFC) Ltd (2001) Report on Evaluation Study of the Scheme of soil Conservation in the Catchment of River Valley Projects and Flood Prone Rivers, Kundah Catchment, Kerala.

Government of India (2008) Common guidelines for watershed Development Projects. Department of Land Resources, Ministry of Rural Development, Government of India.

Joshi PK, Jha AK, Wani SP, Joshi Laxmi, and Shiyani RL (2005) Metaanalysis to assess impact of watershed program and people's participation. Comprehensive Assessment Research Report 8, Comprehensive Assessment Secretariat, International Water Management Institute (IWMI), Colombo, Sri Lanka, pp. 24.

Joshi PK, Jha AK, Wani SP, Sreedevi TK, and Shaheen FA (2008) Impact of Watershed Program and Conditions for Success: A Meta-Analysis Approach. Global Theme on Agroecosystems Report no. 46, Patancheru 502 324, Andhra Pradesh, India: International Crops Research Institute for the Semi-Arid Tropics. pp. 24.

Kerr J, Pangare G, Pangare VL, and George PJ (2000) An Evaluation of Dryland watershed Development in India. EPTD Discussion Paper 68. International Food Policy Research Institute, Washington, DC, USA, pp. 137.

Palanisami K, and Suresh Kumar (2004) Impact Assessment of Select Watersheds in Coimbatore District on Tamil Nadu. Water Technology Centre, Tamil Nadu Agricultural University, Coimbatore, pp. 80.

Patel PP (2005) Salinity Ingress Prevention Circle, Rajkot. In: Rishab Hemani (ed) Impact of Watershed Interventions on Groundwater in Rajasamadhiyala and Downstream Villages. International Water Management Institute, Anand, Gujarat, India.

Pathak P, Wani SP, and Sudi R (2006) Gully Control in SAT Watersheds. Global Theme on Agroecosystems Report No. 15. International Crops Research Institute for the Semi-Arid Tropics, Patancheru 502 324, Andhra Pradesh, India, pp. 29.

Ramasamy K, and Palanisami K (2002) Some Impact Indicators and Experiences of Watershed Development in Drought Prone Areas of Tamil Nadu. In: K Palanisami, Suresh Kumar and Chandrashekaran $B$ (eds.) Watershed management - Issues and policies for 21 st Century. Associated Publishing Company, New Delhi, pp. 182-191.

Rockström J, Karlberg L, Wani SP, Barron J, Hatibu N, Oweis T, Bruggeman A, Farahani J, and Qiang Z (2010) Managing water in rain- 
fed agriculture - The need for a paradigm shift. Agricultural Water Management 97(4): 543-550.

Rosegrant M (2002) Policies and Institutions for Sustainable Water Resource Management: A Research Agenda. Challenge program on water and food, Background paper 5. International Water Management Institute (IWMI), Colombo, Sri Lanka, pp. 35.

Sastry G, Reddy YVR, and Singh HP (2002) Appropriate Policy and Institutional Arrangements for Efficient management of Rainfed watersheds in 21 st Century. In: K Palanisami, Suresh Kumar, and Chandrashekaran B (eds.) Watershed Management - Issues and Policies for 21 st Century. India: Associated Publishing Company. pp. 228324.

Secklar D, Amarasinghe U, Molden D, De Silva R, and Barker P (1998) World water demand and supply 1990 to 2025: Scenarios and issues. Research Report 19, International Water Management Institute (IWMI), Colombo, Sri Lanka, pp.52.

Sahrawat KL, Wani SP, Rego TJ, Pardhasaradhi G, and Murthy KVS (2007) Widespread deficiencies of sulphur, boron and zinc in dryland soils of the Indian semi-arid tropics. Current Science 93 (10): 1 6.

Shiferaw B, Bantilan C, and Wani SP (2006) Policy and institutional issues and impacts of integrated watershed management: Experiences and lessons from Asia. In: Shiferaw B and Rao KPC (eds.) Integrated management of watersheds for agricultural diversification and sustainable livelihoods in Eastern and Central Africa: Lessons and experiences from semi-arid South Asia. Proceedings of the International Workshop, 6-7 December 2004, Nairobi, Kenya, pp. 37-52.

Shiklomanov A Igor (1999) World water resources and their use. International Hydrological Programme, UNESCO's Intergovernmental Scientific Programme in water resources. State Hydrological Institute, St. Petersburg.

Sikka AK, Subhash Chand, Madhu M, and Samra JS (2000) Report on Evaluation Study of DPAP watersheds in Coimbatore District. Central Soil and water Conservation Research and Training Institute, Research Centre, Uthagamandalam, Tamil Nadu.

Sreedevi TK, Wani SP, Sudi R, Patel MS, Jayesh T, Singh SN, and Tushaar Shah (2006) On-site and off-site impact of watershed development: A case study of Rajasamadhiyala, Gujarat, India. Global Theme on Agroecosystems Report No. 20. International Crops Research Institute for the Semi-Arid Tropics, Patancheru 502 324,
Andhra Pradesh, India, pp.52.

Sreedevi TK, Wani SP, and Pathak P (2007) Harnessing Gender Power and Collective Action through Integrated watershed Management for Minimizing Land Degradation and Sustainable Development. Journal of Financing Agriculture 36:23-32.

Sreedevi TK, Wani SP, Sudi R, Harshavardhana K Deshmukh, SN Singh, and Marcella D'Souza (2008) Impact of Watershed Development in Low Rainfall Region of Maharashtra: A case study of Shekta Watershed. Global Theme on Agroecosystems Report No. 49. International Crops Research Institute for the Semi-Arid Tropics, Patancheru 502 324, Andhra Pradesh, India, pp. 52.

Wani SP, Pathak P, Sreedevi TK, Singh HP, and Singh P (2003a) Efficient Management of rainwater for Increased crop Productivity and Groundwater Recharge in Asia. In: Kijne W, Barker R and Molden $D$ (eds.) Water productivity in agriculture: Limits and opportunities for improvement. Cab International, Wallingford, UK, pp. 199-216.

Wani SP, HP Singh, TK Sreedevi, P Pathak, TJ Rego, B Shiferaw, and SR lyer (2003b) Farmer-Participatory Integrated Watershed Management: Adarsha Watershed, Kothapally, India: An Innovative and Upscalable Approach. International Crop Research Institute for the Semi-Arid Tropics, Patancheru 502 324, Andhra Pradesh, India, pp. 26.

Wani SP and Ramakrishna YS (2005) Sustainable Management of Rainwater Through Integrated watershed Approach for Improved rural Livelihood. In: Sharma BR, Samra JS, Scott C and Wani SP (eds.) Watershed management challenges: Improved productivity, resources and livelihoods. International Water Management Institute (IWMI), Colombo, Sri Lanka, pp. 39-60.

Wani SP, Sreedevi TK, TSV Reddy, B Venkateshvaralu, and CS Prasad (2008a) Community watersheds for improved livelihoods through consortium approach in drought prone rainfed areas. Journal of Hydrological Research and Development 23: 55-77.

Wani SP, Joshi PK, Raju KV, Sreedevi TK, Wilson JM, Shah Amita, Diwakar PG, Palanisami K, Marimuthu S, Jha AK, Ramakrishna YS, Meenakshi Sundaram SS, and D'Souza Marcella (2008b) Community Watershed as a Growth Engine for Development of Dryland Areas. A Comprehensive Assessment of Watershed Programs in India. Global Theme on Agroecosystems Report No. 47, International Crops Research Institute for the Semi-Arid Tropics, Patancheru 502 324, Andhra Pradesh, India, pp. 156. 